\title{
Roksana Kacprzak*
}

\section{ANALYSIS OF PRODUCTION PROCESSES IN A GIVEN ENTERPRISE}

\begin{abstract}
A b s t r a c t: The article entitled "Analysis of production processes in a given enterprise" is characterized by a topic related to a production efficiency in a given enterprise and the management of the production process. The aim of the article is to conduct researches and analyzes that improve the management and a course of production process by using key tools. Thank to the implementation of the given methods, the reasons for the difficulties in the production process and the method of their reduction or elimination were identified. The tools that were used to improve the efficiency of the production process in the enterprise, include the usage of Kaizen method, the implementation of Poka Yoke, and the usage of the ERP system. The implementation of these tools will help to achieve better results in the production process.
\end{abstract}

K e y w o r d s: production efficiency, production management, production.

J E L C o d e: L 16, L 21

\section{INTRODUCTION}

In a time of globalization and increasing competition, companies are taking measures to optimize costs, increase efficiency and deliver the product according to customer expectations. It is particularly important to manage production processes, eliminate errors and downtime in these processes and take action to optimize the business.

Processes are activities that support specific areas in the undertaking concerned. They can help you increase efficiency and productivity. Proper process management increases the chance to gain competitive advantage on the background of other companies by efficiently delivering orders with high quality with cost optimization.

\footnotetext{
* Contact information: Państwowa Wyższa Szkoła Zawodowa w Koninie, Wydział Nauk Ekonomicznych i Technicznych, Katedra Nauk Technicznych, ul. Przyjaźni 1, 62-510 Konin, email: kacprzak.roksana9804@gmail.com
} 
The purpose of this article is to analyze the production processes of the selected undertaking, to evaluate them and identify specific activities that will affect liquidity and their effective implementation.

The character of the article is empirical and constitutes a case study. The solutions proposed require further analysis, while ongoing improvement processes are in place.

\section{MANAGEMENT OF PRODUCTION PROCESSES IN ENTERPRISES}

In enterprises, efficient process management is the basis for the implementation of the actions product development. Production processes are activities that occur primarily in the production department [Niziński, Żurek, 2011, p. 137].

The manufacturing process distinguishes between $\mathrm{R} \& \mathrm{D}$, manufacturing process and distribution and customer service, as shown in the chart below [Andrzejczyk, Koliński, Śliwczyński, 2014, p.14].

Picture 1. Processes taking place in the production process

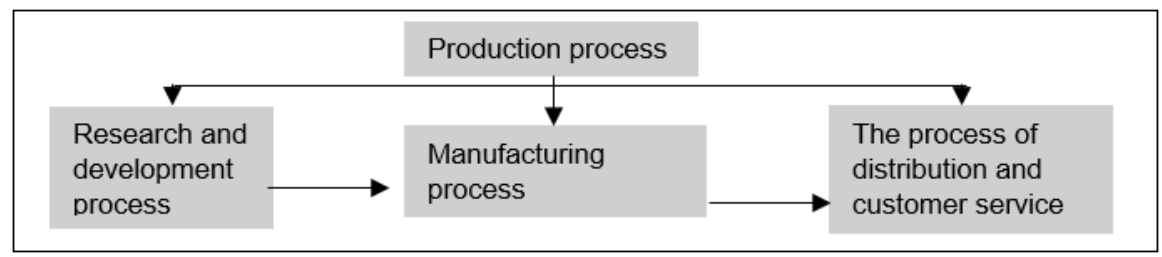

Source: development based on B. Śliwczyński, A. Koliński, P. Andrzejczyk Organizacja i monitorowanie procesów produkcyjnych, Instytut Logistyki i Magazynowania, Poznań 2014, p.14.

The first R\&D (Research and Development) process consists of controlling and monitoring the production planning activities. In addition, he shall be responsible for drawing up and maintaining the relevant documentation necessary for the performance of the contract in question. The production method is then determined according to pre-established product guidelines and standards. This means designing and organizing the production process. The final stage in the $\mathrm{R} \& \mathrm{D}$ process is responsible for the movement of intermediate products between stations in an appropriate quantity [Pająk, 2013, p. 85; Pająk, 2016, p.20].

The next step is the manufacturing process, which is characterized by the transformation of raw materials and intermediate products into a finished product. In order to produce the final product, raw materials and intermediate products are moved between the working stations in the correct order, since each working station adds the appropriate useful value to produce the final product [Durlik, 2004, p. 55; Cieślak, Rogaczewski, 2019, p. 32-33].

The final step is the distribution and customer service process. The main task of this cell is to plan and organize distribution. It is also responsible for activities 
such as scheduling deliveries, determining transport modes and means of transport, and routing. The purpose of the distribution and customer service process is to provide services for as high as possible at the lowest possible cost. This process is necessary to deliver the right quantity to the customer. In addition, the process includes pre-sales customer service and after-sales service to meet customer expectations [Pająk, 2013, s. 85].

The production process must be designed properly to be successful and organize. The aim of the production companies is to achieve the highest possible level of production within a specific unit of time, while maintaining a high level of quality products [Stajniak, 2007, p.92].

Production processes are dependant on the production system that was previously planned. As an essential element, the layout of the workstations in the correct order at least intervals to avoid disturbing the production process. In addition, it is important to monitor the production process continuously. This allows you to quickly detect errors and causes, as well as detect unnecessary movements or actions that do not add value to products. Then, they can be quickly and efficiently eliminated, giving you the time you can spend on the next piece [Niziński, Żurek, 2011, p. 319-320].

The production process should also be used to indicate transport processes, i.e. internal and external. In the production company, internal transport is responsible for the movement of goods within the company of the facility. For example, transportation between stations or transport from internal storage to a production plant. External transport is also outside the company environment. This is, for example, the transport of raw materials necessary for the execution of the order or the transport of goods ready for customers [Michalik, Staniewska, 2010, p. 104,106; Niziński, Żurek, 2011, p. 319-320].

The detailed workflow of the production process is shown in picture 2 .

Picture 2. The course of the production process

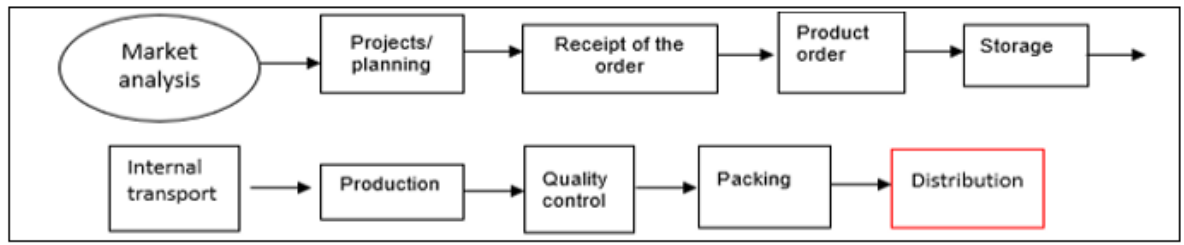

Source: Own-account development based on K. Topolska Modelowanie cyklu produkcyjnego przy użyciu mapowania procesu, ,,czasopismo logistyka” 2014, nb 6., p. 13831-13832.

The graphic above indicates the steps in the production process in the correct order. First of all, demand data should be identified through market research. This allows you to determine the need for a product and to determine the quan- 
tity required to be manufactured to meet your needs. The research will be about learning about the requirements and expectations of potential customers. Then, once the demand has been established, the production process must be properly designed and planned or the raw materials necessary for production must be prepared. The next step is to receive the order and start the order in accordance with the guidelines. Internal transport the initial raw materials necessary for the production to be carried out on a specific working position are moved. However, before transport is carried out, the quality of the finished products must be assessed. Products must be transported to the packing station after successful quality control. After proper packaging and security of the goods, the finished goods are distributed to the customers.

In conclusion, the production process consists of several steps. It is important that all areas work together. This is possible by using Enterprise Resource Planning (ERP) systems in the facility. This system allows fast communication between employees across different areas of the enterprise. It also has a single database that is updated on an ongoing basis, which significantly speeds up and streamlines the process of order fulfillment.

The production system should also be mentioned when analyzing production processes. It transforms the raw materials into finished products. The products are manufactured according to established standards and guidelines to produce the best possible quality. In addition, the production system prepares the order according to customer requirements. This ensures that the customer is happy with the order and can recommend the company to others [Niziński, Żurek, 2011, p. 11; Szymonik, 2012, p. 31].

There are three systems for organizing production [Niziński, Żurek, 2011, p.305]:

- serial port,

- parallel,

- series-parallel.

A serial system is a job of a specific number of intermediate products. Once you have finished working at this workstation, the intermediate products are moved to the next workstation. The next parallel system is responsible for the movement of intermediate products in turn. When you add values to a particular intermediate, the value is then moved to the next station. The series-parallel system, however, consists of a combination of the systems mentioned above. The intermediate products produced are based on the assumptions made from the series system, and when the value is added, the intermediate is transferred to the next station as in the parallel system [Kozłowski, Liwowski, 2014, p. 45-46; Topolska, 2014, p.13832].

Production companies are aiming to produce quality products, so control of production is extremely important. 


\section{ANALYSIS OF SELECTED PRODUCTION PROCESSES - A CASE STUDY}

The production company concerned is involved in the production of paving blocks. It also offers a variety of garden items such as fuel, curbs and open-air construction. The production department is operated in two shifts. 4 employees are employed per shift.

The company is equipped with modern machinery and equipment. In addition, all employees have the necessary experience. The production process is continuously implemented to reduce waste of time. In addition, the workstations are automated at the plant, which means little employee intervention. In this case, the employee is responsible for and in control of the position.

The following is a diagram showing the workstations and the machines in question manufacturing plant.

Picture 3. Scheme of the production hall

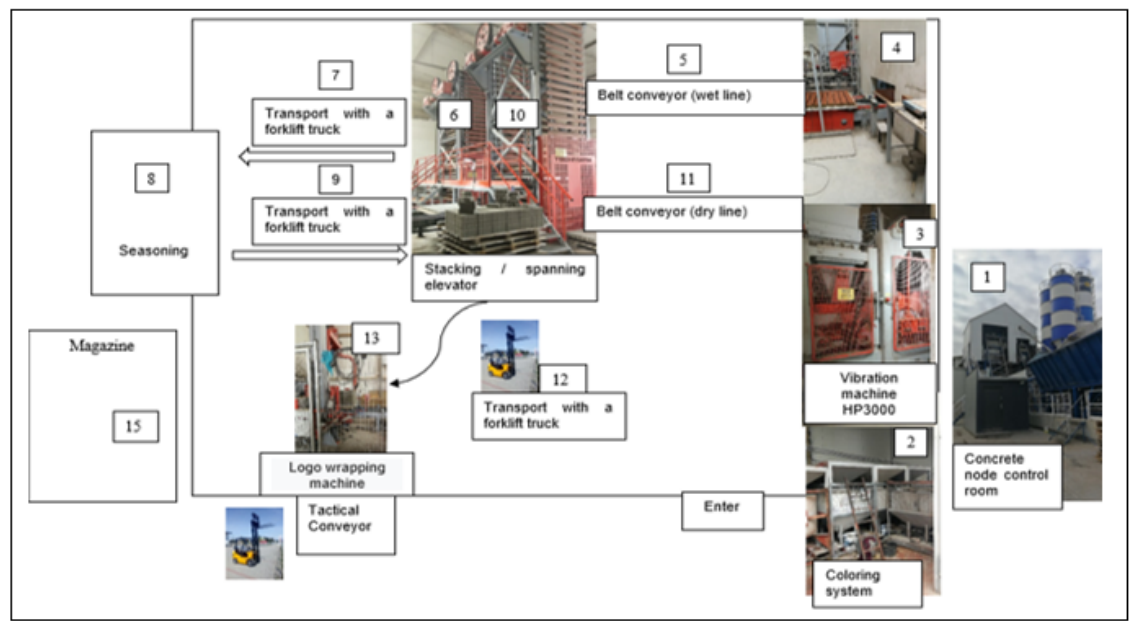

Source: own-account development based on data from the company.

The diagram shown above shows the inside of the production room. Workstations are named and listed exactly in the order in which the production process takes place. It should be noted that the distances between stations are set so that the gaps are as short as possible. Production is continuous in order to produce as many cobbles as possible at a given time, while maintaining the quality of the products.

The design and development of the technology is essential for the production of the cobblestone. The quality of the final product depends on the quality of the products purchased for manufacture. The supplier of aggregates, pigments or concrete chemicals should be a product certificate, and the contracting firm is 
confident in the quality and standards. Then select the supplier and wait for the order to be delivered on the due date. After this, the initial production phase is carried out in the concrete node control room, i.e. the addition of cement silos according to the recipe. When this process is completed, the mixture is transported to the vibrating machine to obtain the correct shape. The mold of the cobblestone is placed in the "seasonal" storage for 24 hours to cool and to accept the correct hardness. After this operation, the cube is ready to be packed and sold.

Picture 4 shows the detailed process of production in the company.

Picture 4 . The course of the production process in the enterprise

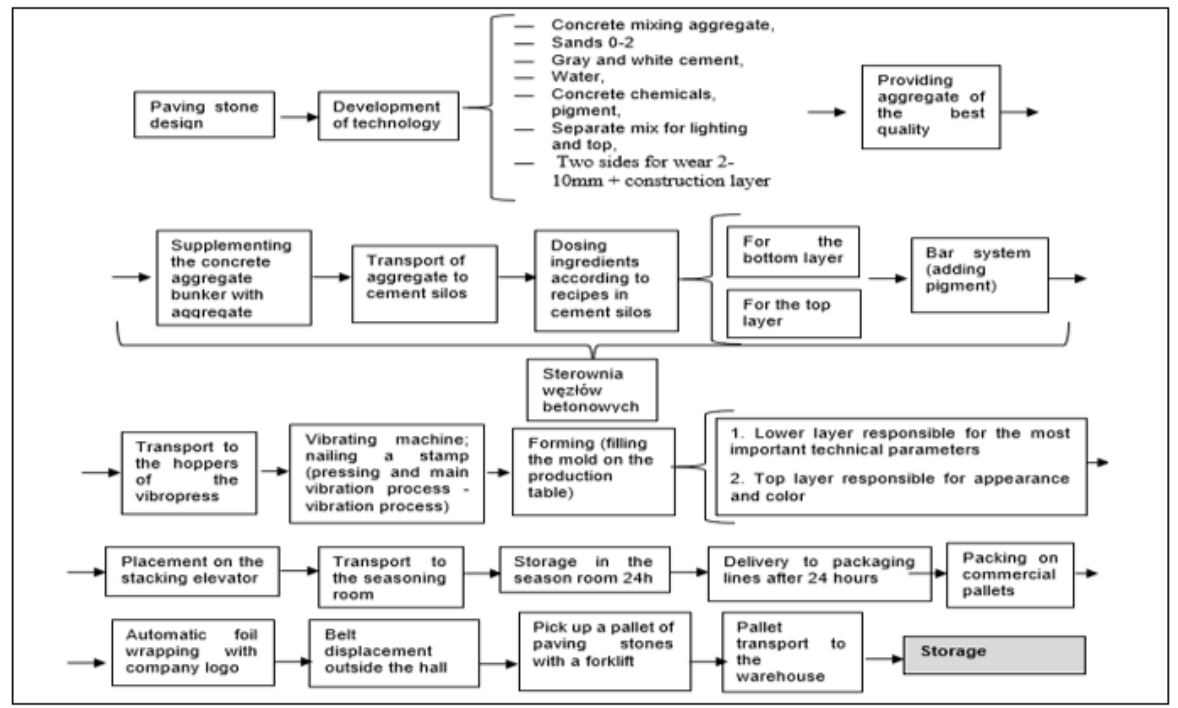

Source: Own-account development based on data from the company.

The above diagram shows the plan according to which the production is carried out in the company concerned. The organization and control of the production process are necessary to achieve the quality and production rate standards indicated. Production process management and workflow must be continually improved to make production results more profitable for the company.

Thank to detailed analysis has detected problems during the production process. The first is a large quantity of a cast. This may be due to poor quality materials used in production, or careless selection of ingredients. Then, a problem with the pigmentation of the cobular and the cement in the cartridge was frozen. These handicaps are linked to a longer production time.

The company needs to continuously improve processes and optimize costs. It is important that the company achieves the highest possible profits with the production of products that meet customer requirements. This will ensure that 
customers are happy and will recommend the company and brand to the next interested party and will return for the next purchase.

Manufacturing process mapping was also used to take any steps to improve the production process. This is essential to be able to check what is being done during the production difficulties.

To improve the production process, the company analyzes all activities using the OEE (Overell equipment Effectivenes). The result indicates to what extent the plant is using full capacity. On the other hand, the efficiency index of the machines and equipment is responsible for information on the utilization of the potential of the machinery during a certain period. This indicates the correct position of the work stations and the time for resetting the machines.

OEE calculations show that the company achieves an underperformance. As a result, the company could suffer losses in sales of the cobblestone by lowering the price when it is selected or by paying the costs when the cube is not suitable for sale and use. In this case, dispose of the cube for disposal, which must also be paid for.

The paving stone that does not reach the quality level is due to poor management of the production process. Moreover, this means that quality losses can result from poor communication of employees. Then there is a risk of confusion, i.e. wrong parameters and wrong selection of ingredients. The operation of the facility is also dependant on the competencies of the employees and their experience and commitment to work. In this situation, it is important to monitor job positions, employee behavior, which will help determine the cause of their disorganization. It is important to motivate employees to improve their productivity. A satisfied employee will demonstrate greater commitment to the job.

On the other hand, the effective working time of machines and equipment is at a high level. This means that the production plant is managing time in the production area. This is due to the proper spread of machinery and equipment, eliminating unnecessary movements or transport. The actions are considered and are focused on eliminating waste of time to produce as many cobbles as possible at a given time.

\section{ACTIVITIES OPTIMIZING THE IMPLEMENTATION OF THE PRODUCTION PROCESS}

The company concerned has been analyzed to identify problems that reduce the efficiency of production. A frequent problem of cement shing in the hopper was detected during the initial production phase, which slows production significantly. To clean and refill the tank to the correct production, stop production until the cement is removed. Then a large number of the cast cubes were discovered. As a result, the company does not realize the profits it can afford. In addition, 
a problem of poor pigmentation of the cobular cobblestone was found. When the cube color is not compatible with the cube offer, it is sold at a lower price. To repair the dye, stop production, remove previous resources and dispose of new ones with correct pigment.

To fix problems, first of all, you should know the cause of the problems. For this purpose, the Ishikawa diagram and the " 5 " why method are used. (pic. 3 ; pic. 4)

Picture 5. Ishikawa diagram on the basis of the problem "missing cube"

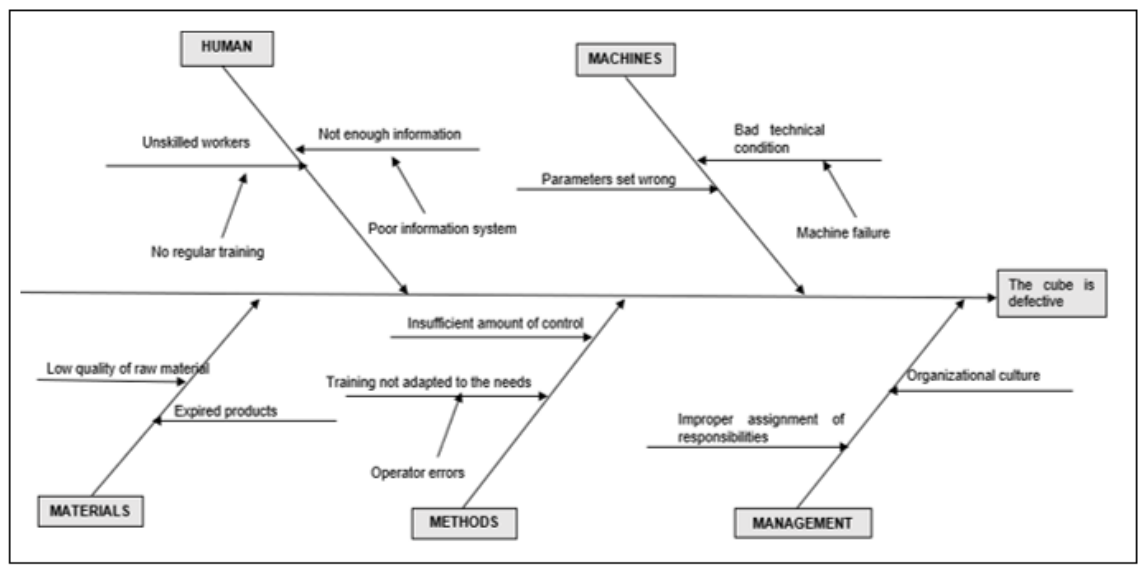

Source: Own-account development based on data from the company.

The chart above indicates the possible cause of the problem. This method allows you to control the area and react quickly to solve the difficulties. Although errors occur at the manufacturing facility, all company environments are searched. This means that the difficulties that arise during production may result from inadequate communication between employees or from a lack of willingness to work as a result of improper incentive or other arrangements.

Table 1. The 5 Why method applied to the problem of "bad paving stone pigmentation"

\begin{tabular}{|c|l|l|}
\hline \multirow{2}{*}{} & \multicolumn{2}{|c|}{ PROBLEM: poor pigmentation of paving stones } \\
\cline { 2 - 3 } & QUESTION & ANSWER \\
\hline $\mathbf{1}$ & $\begin{array}{l}\text { Why is there a bad pigmentation } \\
\text { cobblestones? }\end{array}$ & $\begin{array}{l}\text { Poor paving stone pigmentation occurs due to poorly set } \\
\text { parameters in the dyeing machine. }\end{array}$ \\
\hline $\mathbf{2}$ & $\begin{array}{l}\text { Why are the parameters in the } \\
\text { machine } \\
\text { Wrongly positioned? }\end{array}$ & $\begin{array}{l}\text { The parameters on the machine are set incorrectly } \\
\text { because workers are not cooperating with each other. }\end{array}$ \\
\hline $\mathbf{3}$ & $\begin{array}{l}\text { Why don't the employees } \\
\text { cooperate with each other? }\end{array}$ & $\begin{array}{l}\text { Employees do not cooperate with each other because the } \\
\text { atmosphere at work is unpleasant. }\end{array}$ \\
\hline $\mathbf{4}$ & $\begin{array}{l}\text { Why does work prevail } \\
\text { unpleasant atmosphere? }\end{array}$ & $\begin{array}{l}\text { There is an unpleasant atmosphere at work due to the } \\
\text { employees' lack of commitment to their duties. }\end{array}$ \\
\hline $\mathbf{5}$ & $\begin{array}{l}\text { Why are employees not involved in } \\
\text { fulfilling their duties? }\end{array}$ & $\begin{array}{l}\text { Employees are not involved in fulfilling their duties at } \\
\text { work due to the weak incentive system in the enterprise. }\end{array}$ \\
\hline
\end{tabular}

Source: Own-account development based on data from the company. 
The table above shows that the problem of inadequate pigmentation of the cobular is due to the lack of adequate motivation of workers. Once the incentive system has been improved, employees will be more involved in their responsibilities. In order to prevent the obstacles to the production process previously discussed, the following methods are proposed to improve the production process. First, the cement in the pocket is cold due to inadequate organization and communication between employees. The solution to this problem is to use an ERP system. Then use the Kaizen method to help reduce the selected cube. To avoid any confusion in color matching, it is proposed to use the Poke-Yoke method to inform the employee about the correct use of the machine.

The following diagram shows the production process, taking into account the proposed solutions to eliminate the production difficulties that have arisen to date.

Picture 7. The production process, taking into account the solutions to the difficulties encountered

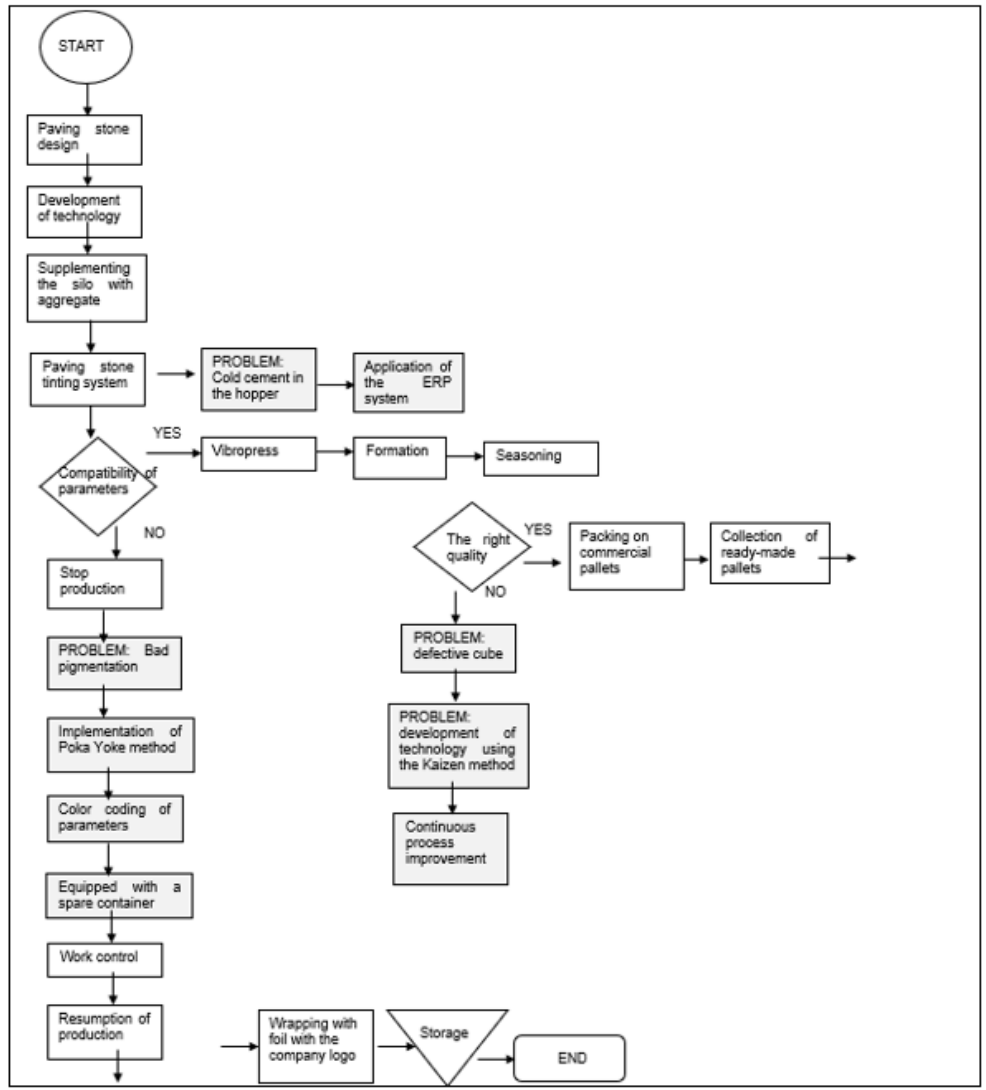

Source: Own-account development based on data from the company. 
Applying ERP to your enterprise will streamline the communication process and eliminate erroneous information by updating your database today. And, Kaizen will enable continuous improvement of business processes by gathering the best ideas from employees to improve the quality of work. The Poka Yoke method will allow you to completely reduce confusion in the cobblestone coloring system. The coloring system may also indicate the choice of coloring agents. Color coded buttons eliminate problem with incorrect pigmentation.

\section{SUMMARY}

The purpose of this Article was to analyze the production process and assess the efficiency of the production process in the company. Despite the company's best efforts to keep the process running continuously to eliminate unnecessary work, difficulties were detected during production. These problems significantly delayed the production process and led to a reduction in the company's profits.

By using a number of analyzes and studies to evaluate the effectiveness of the process and to identify the causes of the difficulties that have arisen, changes in the process have been made. Tools were suggested to improve existing production barriers, i.e. the introduction of an integrated management system (ERP), Kaizen method, and Poka Yoke to improve production workflow.

\section{BIBLIOGRAPHY}

Andrzejczyk P., Koliński A., Śliwczyński B., (2014), Organizacja i monitorowanie procesów produkcyjnych, Instytut Logistyki i Magazynowania, Poznań.

Cieślak R., Rogaczewski R., (2019), Czynniki determinujace efektywność przedsiębiorstw produkcyjnych, PWSZ, Konin.

Durlik I., (2004), Inżynieria zarządzania, strategia i projektowanie systemów produkcyjnych cz. I, PLACET, Warszawa.

Kozłowski R., Liwowski B., (2011) Podstawowe zagadnienia zarzadzania produkcja, JAK, Warszawa.

Michalik J., Staniewska E., (2010) Procesy transportowe w przedsiębiorstwie, „Czasopismo Logistyka", $\mathrm{nr} 4$.

Niziński S., Żurek J., (2011), Logistyka ogólna, WKł, Warszawa.

Pająk E., (2013), Zarządzanie produkcją produkt, technologia, organizacja, PWN, Warszawa.

Pająk E., (2016), Zasady i metody oszczędnego wytwarzania, PWSZ, Konin.

Stajniak M., (2007), Transport i spedycja, Poznań.

Szymonik A., (2012) Logistyka produkcji procesy, systemy, organizacja, Difin, Warszawa.

Topolska K., (2014) Modelowanie cyklu produkcyjnego przy użyciu mapowania procesu, „Czasopismo Logistyka”, nb 6. 